\title{
Insights into the Synthesis of Layered Double Hydroxide (LDH) Nanoparticles: \\ Part 2. Formation Mechanisms of LDH
}

\author{
Xiaodi Sun ${ }^{a}$ and Sandwip K. Dey ${ }^{a, b, *}$ \\ ${ }^{a}$ School for Engineering of Matter, Transport and Energy, Center for Interventional Biomaterials, Ira \\ Fulton College of Engineering, Arizona State University, Tempe, AZ 85281, USA \\ ${ }^{b}$ School of Electrical, Computer and Energy Engineering, Ira Fulton College of Engineering, Arizona \\ State University, Tempe, AZ 85281, USA
}

\begin{abstract}
This study demonstrates the effect of (co)intercalated anion compositions on nanostructure evolution to understand the formation mechanisms of layered double hydroxide (LDH) nanoparticles following coprecipitation and hydrothermal treatments (HT). Initially, the room temperature coprecipitation resulted in amorphous primary nanoparticles that agglomerated at the edges due to low surface charge densities. The reversibility of such agglomeration was determined by the crystalline quality upon HT and consequent surface charge density, which in turn were strongly influenced by the composition of the intercalated anions. Upon crystallization, the agglomerated $\mathrm{Zn}_{2} \mathrm{Al}(\mathrm{OH})_{6}\left(\mathrm{NO}_{3}\right)_{0.3}\left(\mathrm{CO}_{3}\right)_{0.35} \cdot x \mathrm{H}_{2} \mathrm{O}$ primary nanoparticles re-dispersed, but the $\mathrm{Zn}_{2} \mathrm{Al}(\mathrm{OH})_{6}\left(\mathrm{NO}_{3}\right) \cdot x \mathrm{H}_{2} \mathrm{O}$ nanoparticles with much lower stability and higher disorder (especially at the edges) exhibited irreversible agglomeration, and transformed into secondary nanoparticles via aggregational growth. Additionally, the stability studies on $\mathrm{Zn}_{2} \mathrm{Al}(\mathrm{OH})_{6}\left(\mathrm{NO}_{3}\right)_{\mathrm{y}}\left(\mathrm{CO}_{3}\right)_{0.5(1-\mathrm{y})} \cdot x \mathrm{H}_{2} \mathrm{O}$ nanoparticles $(\mathrm{y}=0-1)$ showed that the size difference between the cointercalated anions caused phase separation when $0.9 \geq \mathrm{y} \geq 0.6$, leading to bimodal size distributions. Moreover, the coarsening rates were controlled through the cointercalated anion compositions. By gradually varying the ratio of cointercalated $\mathrm{NO}_{3}{ }^{-}$to $\mathrm{CO}_{3}{ }^{2-}$, monodispersed $\mathrm{Zn}_{2} \mathrm{Al}(\mathrm{OH})_{6}\left(\mathrm{NO}_{3}\right)_{y}\left(\mathrm{CO}_{3}\right)_{0.5(1-}$ y) $x \mathrm{H}_{2} \mathrm{O}(0.5 \geq \mathrm{y} \geq 0)$ nanoparticles with systematic variation in the particle size of $\sim 200-400 \mathrm{~nm}$ were obtained after $\mathrm{HT}$ at $85^{\circ} \mathrm{C}$ for $12 \mathrm{~h}$.
\end{abstract}

\section{INTRODUCTION}

Nanoscience and nanotechnology are having revolutionary impacts on almost every realm of society, especially on health care and nanomedicine, and inorganic ceramic nanoplatforms are major contributors. Traditionally, due to their inherent biocompatibility and stability in physiological environments, ceramics have been attractive for biological applications.[2-5] Recently, a number of 
inorganic theranostic nanoplatforms (i.e. with combined therapeutic and diagnostic attributes), including silica, quantum dot, and magnetic nanoparticles (NPs) have been in various stages of preclinical and clinical development.[6-8] Another inorganic ceramic which holds promise in nanomedicine is the layered double hydroxide $(\mathrm{LDH})$, based on the Hydrotalcite $\left(\mathrm{Mg}_{6} \mathrm{Al}_{2}(\mathrm{OH})_{16} \mathrm{CO}_{3} \cdot 4 \mathrm{H}_{2} \mathrm{O}\right)$ structure. However, the success of any theranostic nanoplatforms in biomedicine is highly contingent on their controlled and reproducible synthesis. In addition to the chemical reactions, the understanding of the formation mechanism, i.e., nanostructure evolution, is critical to the synthesis of NPs with controlled mean particle size (MPS) and monodispersed particle size distribution (PSD). Often, the classical nucleation and growth theory is used to describe the formation of crystalline materials from either ionic or molecular solutes in solutions, where after the spontaneous formation of nuclei, those nuclei with sizes larger than the critical radius continue to grow by the consumption of solutes followed by coarsening. However, such a model is often too simplistic to adequately describe many nanomaterial systems, especially since the following assumptions may not be applicable: (1) nucleation is a one-step process in which only one energy barrier exists, (2) the nucleus grows one monomer at a time, (3) the nucleus is spherical and the details of lattice are neglected, and (4) small clusters are considered to have the same properties as their bulk counterparts.[9] In "bottom-up" solution synthesis of NPs at relatively low temperatures, non-classical arguments based on the interplay of thermodynamics (especially surface energy) and kinetics are needed to explain the nanostructure evolution. Complex formation mechanisms, such as multiphase transformation described by Ostwald step rule,[10, 11] particle-based aggregational growth, $[12,13]$ and oriented attachment growth with or without surfactants[14] have been suggested. Due to the lack of understanding of the formation mechanisms of LDH NPs, the controlled syntheses of many biocompatible compositions to maximize their potential in biomedicine have been severely hindered. Therefore, the central theme of this paper is to carry out systematic studies on effect of (co)intercalated anion compositions on nanostructure evolution to understand the formation mechanisms of LDH NPs.

Two model systems, $\mathrm{Zn}_{2} \mathrm{Al}(\mathrm{OH})_{6}\left(\mathrm{NO}_{3}\right)_{0.3}\left(\mathrm{CO}_{3}\right)_{0.35} \cdot x \mathrm{H}_{2} \mathrm{O}$ and $\mathrm{Zn}_{2} \mathrm{Al}(\mathrm{OH})_{6}\left(\mathrm{NO}_{3}\right) \cdot x \mathrm{H}_{2} \mathrm{O} \mathrm{LDH}$ NPs, which exemplify a very stable and the least stable LDH compositions, respectively, were selected for this study. All the NPs were synthesized by coprecipitation followed by hydrothermal treatment (HT). Note, such a synthesis approach is considered the most refined aqueous solution synthesis method for LDH materials of numerous compositions. The synthesis parameters used in this study were optimized by design of experiments and the detailed procedure was reported in Part 1.[ref] To monitor the nanostructure evolution from the initial coprecipitation at room temperature (RT) to the HT-assisted 
formation of crystalline LDH NPs, and to identify the formation mechanisms in the presence of different anions, a number of advanced characterization techniques, including transmission electron microscopy (TEM), X-ray diffraction (XRD), dynamic light scattering (DLS), and zeta-potential ( $\zeta$ ) techniques, were used.

\section{EXPERIMENTAL SECTION}

\subsection{Materials}

Zinc nitrate hexahydrate $\left(\mathrm{Zn}\left(\mathrm{NO}_{3}\right)_{2} \cdot 6 \mathrm{H}_{2} \mathrm{O}\right)$, aluminum nitrate nonahydrate $\left(\mathrm{Al}\left(\mathrm{NO}_{3}\right)_{3} \cdot 9 \mathrm{H}_{2} \mathrm{O}\right)$, zinc chloride $\left(\mathrm{ZnCl}_{2}\right)$, aluminum chloride hexahydrate $\left(\mathrm{AlCl}_{3} \cdot 6 \mathrm{H}_{2} \mathrm{O}\right)$, sodium carbonate $\left(\mathrm{Na}_{2} \mathrm{CO}_{3}\right)$, and sodium hydroxide $(\mathrm{NaOH})$ were purchased from Sigma (St. Louis, MO, USA), used as received, and stored under nitrogen gas $\left(\mathrm{N}_{2}\right)$ environment. Deionized nanopure water (Barnstead, $18.2 \mathrm{M} \Omega \mathrm{cm}$ ), used for the synthesis, was degassed by boiling in advance.

\subsection{Synthesis method}

All the syntheses of ( $\mathrm{Zn}, \mathrm{Al})$-LDH NPs were carried out using the coprecipitation at constant $\mathrm{pH}$ method followed by HT, the details of which are reported in Part 1 paper.[ref] To control the content of $\mathrm{CO}_{3}{ }^{2-}$ within $(\mathrm{Zn}, \mathrm{Al})-\mathrm{LDH}$ NPs as accurately as possible, all chemicals were stored in a $\mathrm{N}_{2}$ filled glove box (MBraun Labmaster 130). Also, all coprecipitations were carried out within the glove box and the products were withdrawn in sealed hydrothermal bottles. Typically, a $10 \mathrm{ml}$ of mixed nitrate salt solution containing $20 \mathrm{mM}$ of total salt concentration ([Zn+Al]), with the $\mathrm{Zn}$ to $\mathrm{Al}$ molar ratio of 2:1, and another $10 \mathrm{ml} \mathrm{NaOH}$ solution containing a designed amount of $\mathrm{Na}_{2} \mathrm{CO}_{3}$, with the concentration of $\mathrm{NaOH}$ being twice that of $[\mathrm{Zn}+\mathrm{Al}]$, were simultaneously added into a round bottom flask (Chemglass

$100 \mathrm{ml}$ round bottom flask) using burettes, while stirring at $3000 \mathrm{rpm}$ (Magnetic stirrer: manufactured by Barnant Corp., Barrington, IL, Model 700.0111). After completion of the addition of $20 \mathrm{ml}$ precursors at an addition rate of $0.589 \mathrm{ml} / \mathrm{s}$, stirring was continued for another 3 minutes to ensure thorough mixing. The mixture was then transferred into the hydrothermal bottle (PYREX screw cap 100 $\mathrm{ml}$ storage bottle), and the HT was carried out at a designed temperature $\left(\mathrm{T}_{\mathrm{HT}}\right)$ for a specific period of time $\left(\mathrm{t}_{\mathrm{HT}}\right)$. Finally, the colloidal suspension was cooled to RT, and centrifuged (Eppendorf 5810R) to collect the gel-like ( $\mathrm{Zn}, \mathrm{Al})$-LDH NPs for physicochemical characterization. The final pH was typically around 5.98-6.15. 


\subsection{Characterization of LDH NPs}

The crystalline phase was determined by powder X-ray diffraction (XRD; Rigaku D/Max-IIB instrument with $\mathrm{Cu}-\mathrm{K}_{\alpha}$ radiation, $\lambda=0.154059 \mathrm{~nm}$ ) in the $2 \theta$ range of $7.5-70^{\circ}$. Inductively coupled plasma atomic emission spectroscopy (ICP, iCAP 6300 ICP Spectrometer) was used to confirm the elemental compositions. Dynamic light scattering (DLS, PSS-NICOMP 380 with zeta potential capability) was used to extract the mean hydrodynamic radius $\left(\mathrm{r}_{\mathrm{H}}\right)$ of the NPs and PSD. Transmission electron microscopy (FEG TEM; Philips CM200 with an electron acceleration voltage of $200 \mathrm{kV}$ ), in bright field imaging mode, was used to follow the evolution of the particle size and morphology to corroborate with the DLS results, and crystallographic information was obtained by selected area electron diffraction.

\subsubsection{Structure evolution and determination of the formation mechanisms of LDH NPS}

$\mathrm{Zn}_{2} \mathrm{Al}(\mathrm{OH})_{6}\left(\mathrm{NO}_{3}\right)_{0.3}\left(\mathrm{CO}_{3}\right)_{0.35} \cdot x \mathrm{H}_{2} \mathrm{O}$ and $\mathrm{Zn}_{2} \mathrm{Al}(\mathrm{OH})_{6}\left(\mathrm{NO}_{3}\right) \cdot x \mathrm{H}_{2} \mathrm{O}$ LDH NPs were synthesized at RT following the procedure described above and used as the model systems to determine the formation mechanisms. For $\mathrm{Zn}_{2} \mathrm{Al}(\mathrm{OH})_{6}\left(\mathrm{NO}_{3}\right)_{0.3}\left(\mathrm{CO}_{3}\right)_{0.35} \cdot x \mathrm{H}_{2} \mathrm{O} \mathrm{NPs}$, the HTs were carried out at $85^{\circ} \mathrm{C}$ for up to 7 h. The evolution of morphology, crystallinity, NP size, PSD, and surface charge were monitored by TEM imaging, electron diffraction and zeta-potential techniques, immediately after the coprecipitation and at different stages of the HT. For $\mathrm{Zn}_{2} \mathrm{Al}(\mathrm{OH})_{6}\left(\mathrm{NO}_{3}\right) \cdot x \mathrm{H}_{2} \mathrm{O}$ LDH NPs, the HTs were carried out at three different $\mathrm{T}_{\mathrm{HT}}$, i.e. 51,70 and $85^{\circ} \mathrm{C}$, for up to $15 \mathrm{~h}$. Again, the evolution of morphology, crystallinity, NP size, and PSD were monitored by TEM, XRD, and DLS techniques immediately after the coprecipitation, and at different stages of the HTs.

\subsubsection{Size difference between the cointercalated anions-induced phase separation}

The study of phase separation due to the size difference of the cointercalated anions was carried out by comparing two different systems of varying compositions as follows: $\mathrm{Zn}_{2} \mathrm{Al}(\mathrm{OH})_{6}\left(\mathrm{NO}_{3}\right)_{\mathrm{y}}\left(\mathrm{CO}_{3}\right)_{0.5(1-\mathrm{y})} \cdot x \mathrm{H}_{2} \mathrm{O}(\mathrm{y}=0-1.0)$ and $\mathrm{Zn}_{2} \mathrm{Al}(\mathrm{OH})_{6}(\mathrm{Cl})_{0.7}\left(\mathrm{CO}_{3}\right)_{0.15} \cdot x \mathrm{H}_{2} \mathrm{O}$. The resulting particle sizes and PSD, and crystalline phases were characterized by DLS and XRD, respectively.

\subsubsection{Cointercalated anion composition-controlled coarsening}

Samples of $\mathrm{Zn}_{2} \mathrm{Al}(\mathrm{OH})_{6}\left(\mathrm{NO}_{3}\right)_{\mathrm{y}}\left(\mathrm{CO}_{3}\right)_{0.5(1-\mathrm{y})} \cdot x \mathrm{H}_{2} \mathrm{O}(\mathrm{y}=0.5,0.4,0.3,0.2,0)$ were synthesized by coprecipitation at RT, followed by $\mathrm{HT}$ at $85{ }^{\circ} \mathrm{C}$ for $12 \mathrm{~h}$. The resulting particle sizes and PSD were monitored by TEM and DLS techniques. 


\section{RESULTS AND DISCUSSIONS}

\subsection{Formation mechanisms of LDH NPs}

The electrostatic bonding strength between different intercalated anions within the interlayer space and double hydroxide layers can vary significantly,[15] which in turn can affect the stabilities of LDHs in a significant manner.[16, 17] A thermo-chemical study showed that with the introduction of only $1.47 \%$ of the $\mathrm{NO}_{3}^{-}$anion, the $\Delta \mathrm{H}_{\mathrm{f}}^{0}\left(-991.79 \mathrm{KJmol}^{-1}\right)$ for pure $\mathrm{CO}_{3}{ }^{2-}$-intercalated $\mathrm{LDH}$ $\left(\mathrm{Co}_{0.756} \mathrm{Al}_{0.244}(\mathrm{OH})_{2}\left(\mathrm{CO}_{3}\right)_{0.122} \cdot 0.805 \mathrm{H}_{2} \mathrm{O}\right)$ changed to $-967.89 \mathrm{KJmol}^{-1}$ for mixed $\left(\mathrm{CO}_{3}^{2-}, \mathrm{NO}_{3}{ }^{-}\right)-$ cointercalated $\mathrm{LDH}\left(\mathrm{Co}_{0.756} \mathrm{Al}_{0.244}(\mathrm{OH})_{2}\left(\mathrm{CO}_{3}\right)_{0.1202}\left(\mathrm{NO}_{3}\right)_{0.0036} \cdot 0.805 \mathrm{H}_{2} \mathrm{O}\right)$, indicating the higher stability of the former.[17] Therefore, it was anticipated that intercalated anion composition could have an influence on the formation mechanisms of LDH NPs. Consequently, $\mathrm{Zn}_{2} \mathrm{Al}(\mathrm{OH})_{6}\left(\mathrm{NO}_{3}\right)_{0.3}\left(\mathrm{CO}_{3}\right)_{0.35} \cdot x \mathrm{H}_{2} \mathrm{O}$ and $\mathrm{Zn}_{2} \mathrm{Al}(\mathrm{OH})_{6}\left(\mathrm{NO}_{3}\right) \cdot x \mathrm{H}_{2} \mathrm{O}$ NPs were used as nanoparticulate model systems, and representing the cases of the very strong and the weakest electrostatic bond strength, respectively.

\subsubsection{Nanostructure evolution of $\mathrm{Zn} 2 \mathrm{Al}(\mathrm{OH})_{6}\left(\mathrm{NO}_{3}\right)_{0.3}\left(\mathrm{CO}_{3}\right)_{0.35} \cdot \mathrm{xH}_{2} \mathrm{O}$ nanoparticles}

Figures 1 and 2 illustrate the time evolution of the morphology, crystallinity, as well as surface charge determined by bright-field TEM imaging, electron diffraction, and zeta-potential measurements, respectively, for $\mathrm{Zn}_{2} \mathrm{Al}(\mathrm{OH})_{6}\left(\mathrm{NO}_{3}\right)_{0.3}\left(\mathrm{CO}_{3}\right)_{0.35} \cdot \mathrm{xH}_{2} \mathrm{O}$ NPs. The composition of the as-precipitated primary NPs, determined by ICP, was $\mathrm{Zn}_{1.902} \mathrm{Al}(\mathrm{OH})_{5.804}\left(\mathrm{NO}_{3}\right)_{0.3}\left(\mathrm{CO}_{3}\right)_{0.35} \cdot \mathrm{xH}_{2} \mathrm{O}$, and the particle sizes $(\sim 180 \mathrm{~nm})$ were quite uniform (Figure 1a), indicating optimum coprecipitation conditions. 

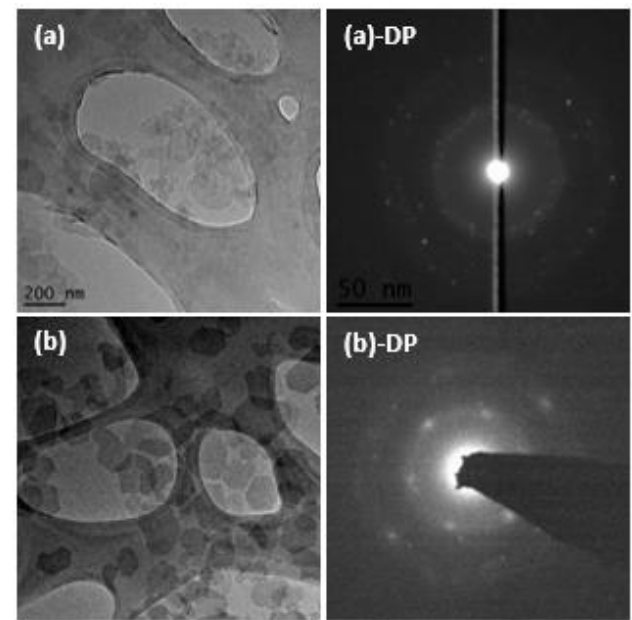

(b)-DP
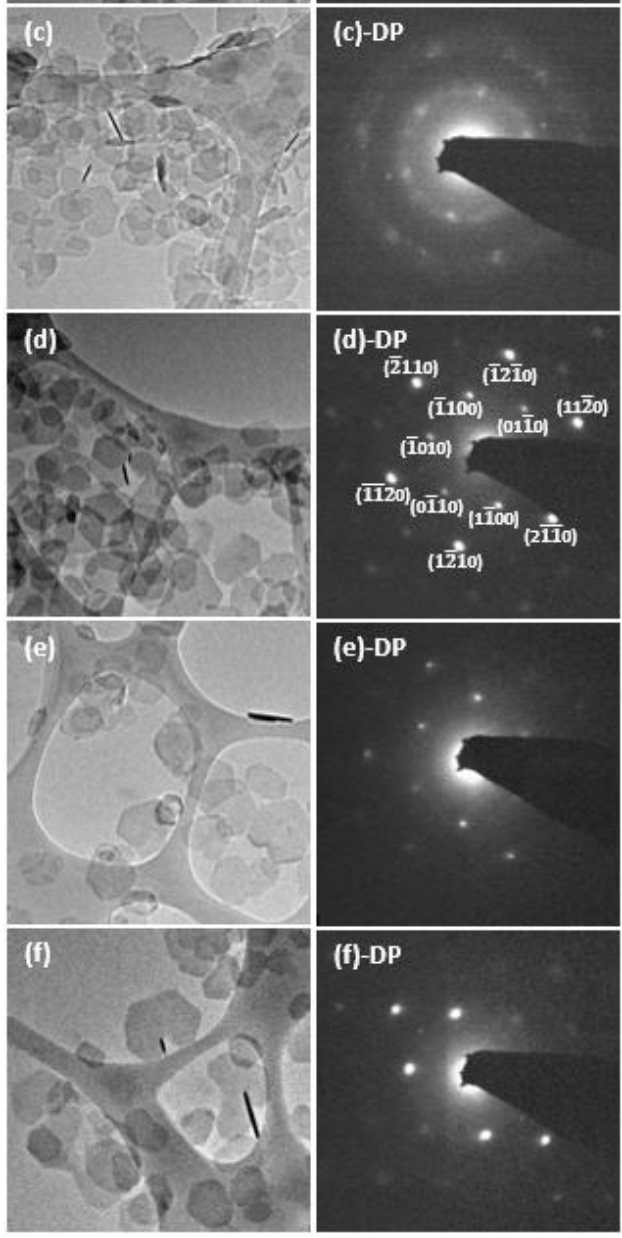

Figure 1. TEM study of the morphology and crystallinity evolution of $\mathrm{Zn}_{2} \mathrm{Al}(\mathrm{OH})_{6}\left(\mathrm{NO}_{3}\right)_{0.3}\left(\mathrm{CO}_{3}\right)_{0.35} \cdot \mathrm{xH}_{2} \mathrm{O}$ nanoparticles from the as-precipitated amorphous nanoparticles at RT until the formation of fully crystalline nanoparticles during the hydrothermal treatment. The bright field TEM micrographs show the morphologies of the asprecipitated nanoparticles and nanoparticles after being hydrothermally treated at $85{ }^{\circ} \mathrm{C}$ for $1,2,3,5$ and $7 \mathrm{~h}$ in (a), (b), (c), (d), (e), and (f), respectively (left column). Their corresponding electron diffraction patterns with [0001] zone axis are shown in (a)-DP, (b)-DP, (c)-DP, (d)-DP, (e)-DP and (f)-DP, respectively (right column).

As reflected in the diffused rings with weak spots in the diffraction pattern (Figure 1a-DP), the kinetically-preferred primary NPs are amorphous with nanocrystalline domains. Additionally, during 
growth in an aqueous medium at RT, the high-energy edge surfaces grow at a higher rate than the lowenergy (0001) basal surface resulting in the overall discoid shape that minimizes the surface energy. Moreover, the $\zeta$, which is the key indicator of stability of NPs, was found to be about $+36.5 \mathrm{mV}$ (Figure 2; $\left.\mathrm{Zn}_{1.902} \mathrm{Al}(\mathrm{OH})_{5.804}\left(\mathrm{NO}_{3}\right)_{0.3}\left(\mathrm{CO}_{3}\right)_{0.35} \times \mathrm{xH}_{2} \mathrm{O}\right)$; the positive value is consistent with the positively charged nature of the $\mathrm{LDH}$ layers due to isomorphous substitution of the $\mathrm{Zn}^{2+}$ by $\mathrm{Al}^{3+}$. Note, a colloidal dispersion with high stability typically exhibits a $\zeta$ of $\pm 40-60 \mathrm{mV}$ and for moderate stability, a value between $\pm 30-40 \mathrm{mV}$.[18, 19] Despite the expected moderate stability, some agglomeration at the edges of the discoid-shaped NPs was observed in the TEM micrograph (Figure 1a). Because the positive surface charge mainly stems from the (0001) basal surface, surface energy is preferentially lowered by hydration, with a high enthalpy of hydration, which results in impeded growth in the [0001] direction and agglomeration. In contrast, the disordered edges with low charge density reduce the surface energy via the observed agglomeration.

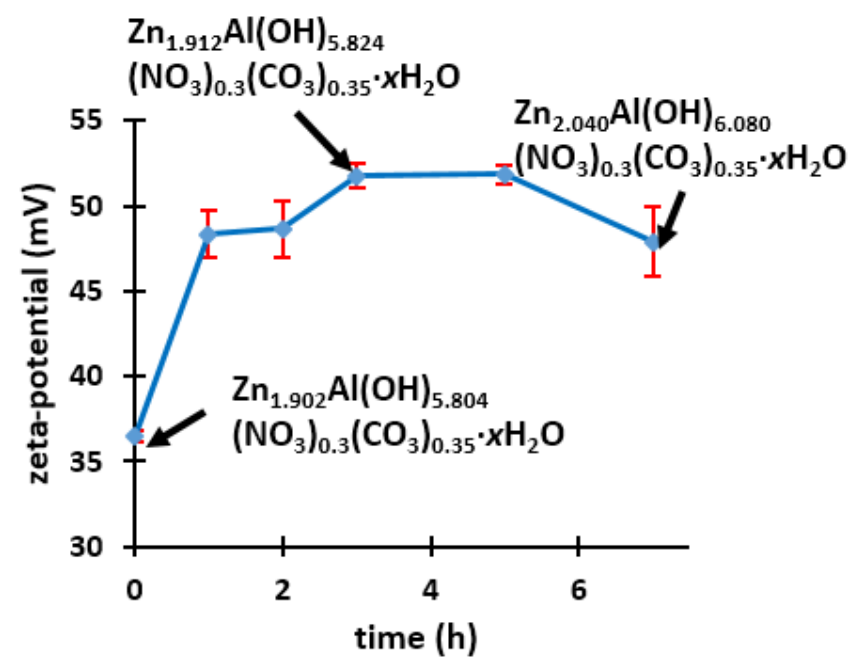

Figure 2. Variation of zeta-potential from the as-precipitated state through hydrothermal treatments at $85{ }^{\circ} \mathrm{C}$ up to 7 hours

The nanostructure evolution during the HT at $85{ }^{\circ} \mathrm{C}$ is shown in Figures $1 \mathrm{~b}-\mathrm{d}$ with their corresponding diffraction patterns (DPs). The as-precipitated NPs underwent phase transformation to the fully crystalline phase within $3 \mathrm{~h}$, the $\zeta$ increased to $+51.8 \mathrm{mV}$ (Figure 2; $\left.\mathrm{Zn}_{1.912} \mathrm{Al}(\mathrm{OH})_{5.824}\left(\mathrm{NO}_{3}\right)_{0.3}\left(\mathrm{CO}_{3}\right)_{0.35} \cdot x \mathrm{H}_{2} \mathrm{O}\right)$, and absolutely no agglomeration was observed. The latter two can be explained by improved crystallinity, increased charge density on all surfaces and hydration, especially at the ordered edges of hexagonally-shaped NPs.

As the HT progressed, the size of the as-precipitated NPs gradually increased from 180 to 230 $\mathrm{nm}$ (Figures 1a-1f). Additionally, the molar ratio of $\mathrm{Al}^{3+} / \mathrm{Zn}^{2+}$ of the LDH NPs from the as-precipitated state up to the HT exhibited changes with increasing $\mathrm{t}_{\mathrm{HT}}(0.526$ for as-precipitated, 0.523 for $3 \mathrm{~h}$ HT, 
and 0.490 for $7 \mathrm{~h} \mathrm{HT}$ ). The $\zeta$ also increased but saturated at $+51.87 \mathrm{mV}$ in $5 \mathrm{~h}$, after which a diminution was observed; note, at $7 \mathrm{~h}$, the $\zeta$ was $+47.89 \mathrm{mV}$ (Figure $2 ; \mathrm{Zn}_{2.040} \mathrm{Al}(\mathrm{OH})_{6.080}\left(\mathrm{NO}_{3}\right)_{0.3}\left(\mathrm{CO}_{3}\right)_{0.35} \cdot x \mathrm{H}_{2} \mathrm{O}$ ), although the diffraction pattern was invariant in comparison to $5 \mathrm{~h} \mathrm{HT}$. The $\mathrm{t}_{\mathrm{HT}}$ and $\mathrm{T}_{\mathrm{HT}}$-dependent HT simultaneously promotes (a) phase transformation of the metastable phase to the thermodynamically stable crystalline LDH NPs via atomic rearrangement and (b) coarsening process via a surface dissolution of NPs with high surface energy followed by re-precipitation of the $\mathrm{Zn}^{2+}$ and $\mathrm{Al}^{3+}$ species. At the early stages of HT, when the NPs are predominantly amorphous with a high surface energy, the high dissolution rate should translate to high supersaturations of $\mathrm{Al}^{3+}$ and $\mathrm{Zn}^{2+}$. The reprecipitated $\mathrm{Al}^{3+} / \mathrm{Zn}^{2+}$ ratio in the LDH can be maintained. However, in the latter stages of HT, once the NPs are completely crystallized, the dissolution rate can decrease significantly due to the much lower solubility of crystalline LDH compared to their amorphous counterparts.[20] Under an almost equilibrium condition, the dissolution gives rise to an excess of $\mathrm{Zn}^{2+}$ and $\mathrm{Al}^{3+}$ with a ratio of 2:1 to the solution. However, since the $\mathrm{K}_{\mathrm{sp}}$ of $\mathrm{Al}(\mathrm{OH})_{3}$ is of almost 16 orders of magnitude lower than the $\mathrm{K}_{\mathrm{sp}}$ of $\mathrm{Zn}(\mathrm{OH})_{2}$ (at $25{ }^{\circ} \mathrm{C}$, $\mathrm{K}_{\mathrm{sp}}\left(\mathrm{Zn}(\mathrm{OH})_{2}\right)=4.1 \times 10^{-17}$ and $\left.\mathrm{K}_{\mathrm{sp}}\left(\mathrm{Al}(\mathrm{OH})_{3}\right)=1.9 \times 10^{-33}\right)$, the large difference in supersaturation can facilitate the rapid precipitation of $\mathrm{Al}^{3+}$ in the form of $\mathrm{Al}(\mathrm{OH})_{3}$; the experimentally-observed whitish solution was indeed indicative of very fine $\mathrm{Al}(\mathrm{OH})_{3} \mathrm{NPs}$. In essence, at the latter stage of HT as the NPs coarsen via the surface dissolution-reprecipitation process, the newly-reprecipitated LDH phase added to the as-precipitated NPs becomes slightly $\mathrm{Al}^{3+}$-deficient, and therefore, less positively charged.

\subsubsection{Nanostructure evolution of $\mathrm{Zn}_{2} \mathrm{Al}(\mathrm{OH})_{6}\left(\mathrm{NO}_{3}\right) \cdot x \mathrm{H}_{2} \mathrm{O}$ nanoparticles}

The nanostructure evolution of $\mathrm{Zn}_{2} \mathrm{Al}(\mathrm{OH})_{6}\left(\mathrm{NO}_{3}\right) \cdot \mathrm{xH}_{2} \mathrm{O}$, which exhibits a much lower stability compared to $\mathrm{Zn}_{1.902} \mathrm{Al}(\mathrm{OH})_{5.804}\left(\mathrm{NO}_{3}\right)_{0.3}\left(\mathrm{CO}_{3}\right)_{0.35} \cdot \mathrm{xH}_{2} \mathrm{O}$, was also studied to determine significant differences in terms of the morphology of as-precipitated NPs and formation mechanism during HT.

The as-precipitated, primary $\mathrm{Zn}_{2} \mathrm{Al}(\mathrm{OH})_{6}\left(\mathrm{NO}_{3}\right) \cdot \mathrm{xH}_{2} \mathrm{O}$ NPs (discoid-shaped and $\sim 70 \mathrm{~nm}$ ) exhibited severe agglomeration at the edges (in Figure 3), despite a measured $\zeta$ of $43.13 \mathrm{mV}$. In aqueous medium, these NPs were highly polydispersed and the mean $r_{H}$ was nearly $7 \mu \mathrm{m}$ as determined by DLS (Figure 4 and inset at time, $\mathrm{t}=0 \mathrm{~h}$ ). The small primary NP size and high agglomeration tendency in this composition compared to $\mathrm{Zn} 2 \mathrm{Al}(\mathrm{OH})_{6}\left(\mathrm{NO}_{3}\right)_{0.3}\left(\mathrm{CO}_{3}\right)_{0.35} \cdot x \mathrm{H}_{2} \mathrm{O}$ can be explained as follows. During coprecipitation, both homogeneous nucleation and growth processes compete to reduce the supersaturation (i.e. $\sigma=\ln \frac{Q_{s p}}{K_{s p}}$; where $\mathrm{Q}_{\mathrm{SP}}$ is the ion product and $\mathrm{K}_{\mathrm{sp}}$ is the solubility product constant) of the solutes, and consequent NP size is dependent on these rates. If $\sigma$ is extremely high, the 
size of the critical nucleus can be smaller than an unit cell dimension, and the induction time (inverse of the nucleation rate) can approach to zero.[20] The growth rate is dictated by the difference between the fluxes of ionic species involved in the attachment to and detachment from the growth surface. Under strong convection, the former is high, whereas the latter is solely influenced by the bond strength.[20] In the current study, the initial $\sigma$ and stirring rate in the coprecipitation conditions of the synthesis of both compositions were about the same (97.4 and $3000 \mathrm{rpm}$, respectively) and rather high. Therefore, the smaller primary $\mathrm{NP}$ size of $\mathrm{Zn}_{2} \mathrm{Al}(\mathrm{OH})_{6}\left(\mathrm{NO}_{3}\right) \cdot \mathrm{xH}_{2} \mathrm{O} \quad\left(\begin{array}{lll}\sim 0 & \mathrm{~nm}) & \text { compared to }\end{array}\right.$ $\mathrm{Zn}_{2} \mathrm{Al}(\mathrm{OH})_{6}\left(\mathrm{NO}_{3}\right)_{0.3}\left(\mathrm{CO}_{3}\right)_{0.35} \cdot x \mathrm{H}_{2} \mathrm{O}(180 \mathrm{~nm})$ can be attributed to the higher detachment rate stemming from the weaker electrostatic bond strength in the former. Additionally, the severe agglomeration in $\mathrm{Zn}_{2} \mathrm{Al}(\mathrm{OH})_{6}\left(\mathrm{NO}_{3}\right) \cdot \mathrm{xH}_{2} \mathrm{O}$ composition can be explained by its highly amorphous nature, i.e., decreased charge sites and lowered hydration enthalpy on the disordered edges of the NPs. Therefore, HT was necessary to improve the crystallinity so as to form stable colloidal suspensions via electrostatic stabilization.

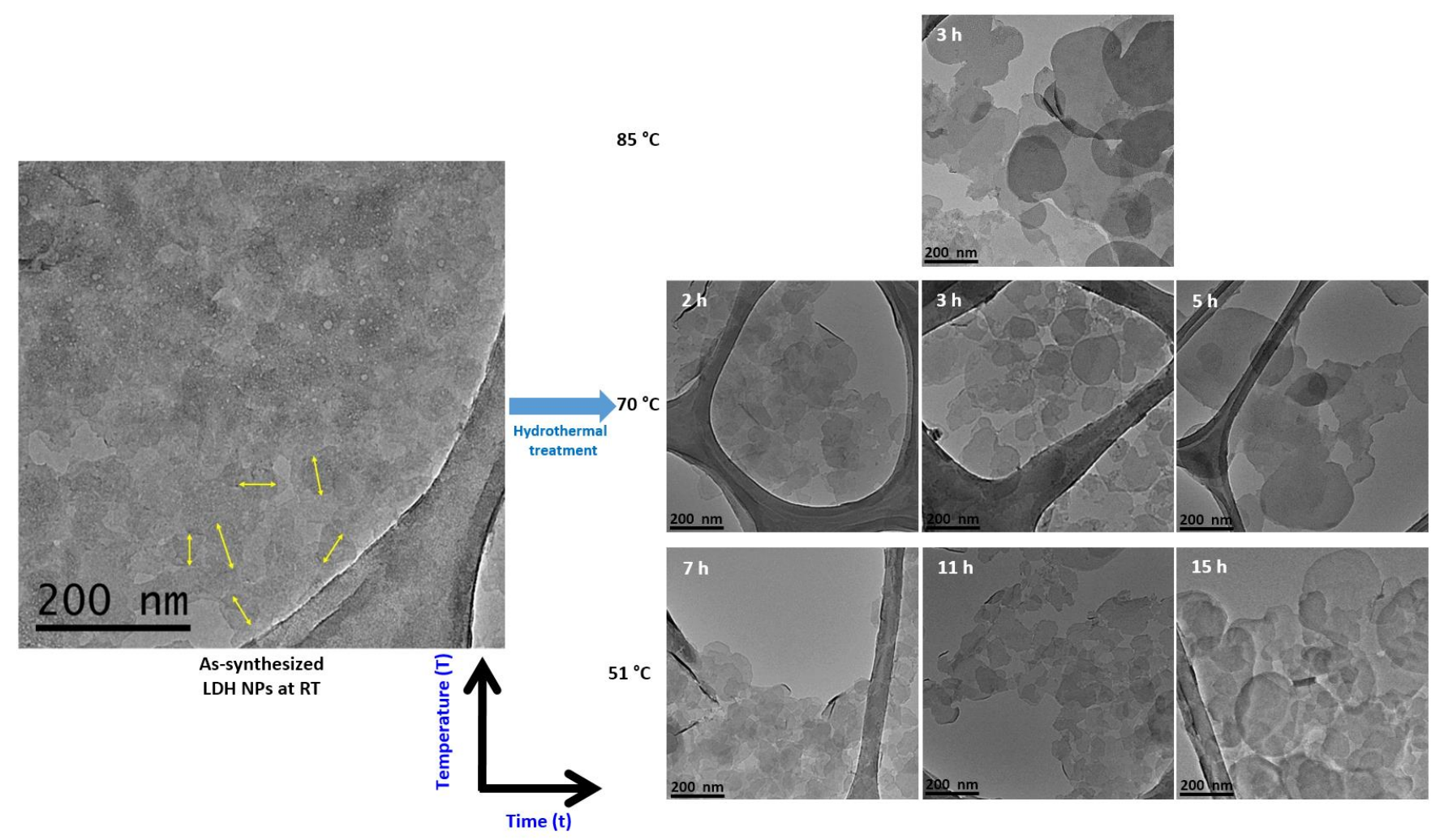

Figure 3. Effect of the $\mathrm{T}_{\mathrm{HT}}$ and $t_{\mathrm{HT}}$ of the hydrothermal treatment on the resulting morphology evolution from the asprecipitated amorphous materials towards the formation of crystalline $\mathrm{Zn}_{2} \mathrm{Al}(\mathrm{OH})_{6} \quad\left(\mathrm{NO}_{3}\right) \cdot \mathrm{xH}_{2} \mathrm{O} \quad \mathrm{LDH}$ nanoparticles 


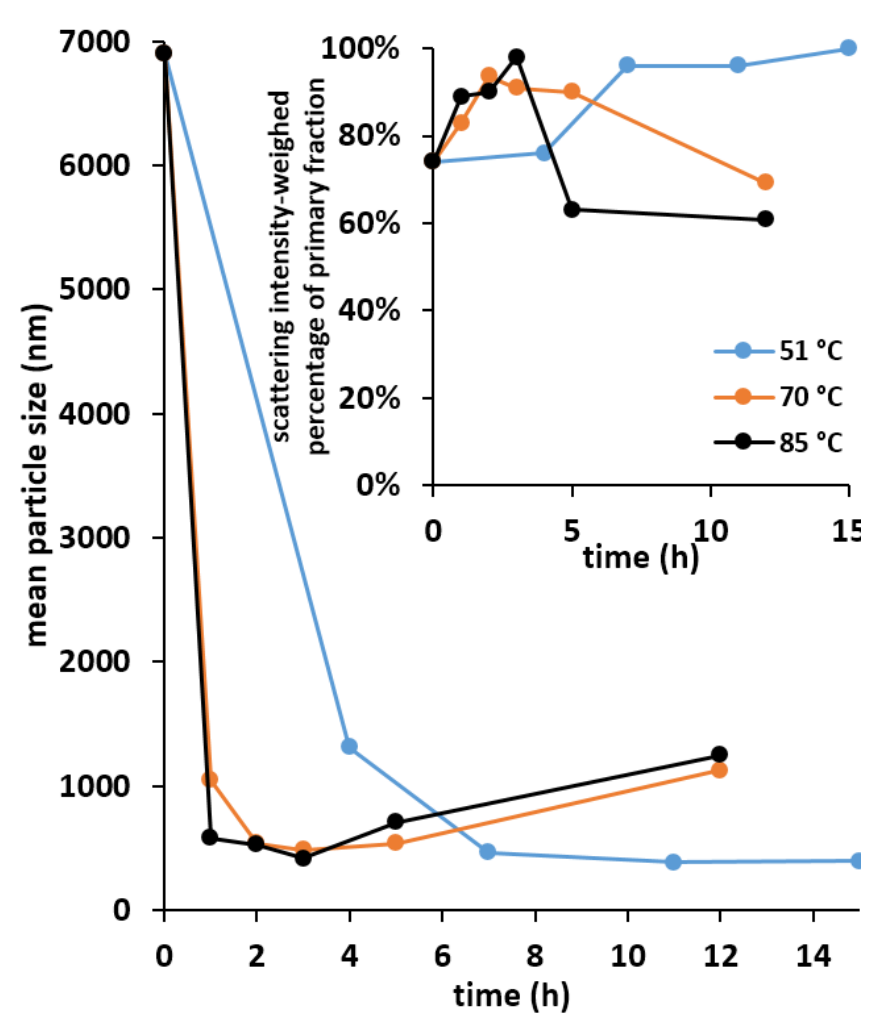

Figure 4. Evolution of the particle size and scattering intensity-weighed percentage of the primary fraction of LDH NPs, measured by DLS at different $\mathrm{T}_{\mathrm{HT}}$ for different $\mathrm{t}_{\mathrm{HT}}$

The HT at $85{ }^{\circ} \mathrm{C}$ rapidly dispersed the severely agglomerated, as-precipitated LDH NPs into stable suspensions; at $t_{\mathrm{HT}}=3 \mathrm{~h}$, the mean $\mathrm{r}_{\mathrm{H}}$ was about $415 \mathrm{~nm}$ and the system exhibited monodispersity (inset of Figure 4 at $t_{\mathrm{HT}}=3 \mathrm{~h}$ ). The corresponding TEM micrograph in Figure 3 shows the discoidshaped NPs with rounded edge. However, longer HT times led to particle coarsening and loss of monodispersity. After $5 \mathrm{~h}$ of HT, the mean $\mathrm{r}_{\mathrm{H}}$ increased to $700 \mathrm{~nm}$, and the scattering intensity-weighed percentage of the primary fraction decreased to $63 \%$ (in inset of Figure 4 at $\mathrm{t}_{\mathrm{HT}}=5 \mathrm{~h}$ ) from $98 \%$ at $\mathrm{t}_{\mathrm{HT}}=$ $3 \mathrm{~h}$. The much higher coarsening rate of these NPs compared to that of $\mathrm{Zn}_{2} \mathrm{Al}(\mathrm{OH})_{6}\left(\mathrm{NO}_{3}\right)_{0.3}\left(\mathrm{CO}_{3}\right)_{0.35} \cdot x \mathrm{H}_{2} \mathrm{O}$ NPs at the same $\mathrm{T}_{\mathrm{HT}}$ is due to the lower stability and higher dissolution rate.

After HT at $70{ }^{\circ} \mathrm{C}$ for $2 \mathrm{~h}$ (or $3 \mathrm{~h}$ ), nearly monodispersed NPs with a mean $\mathrm{r}_{\mathrm{H}}$ of $\sim 540 \mathrm{~nm}$ (or $484 \mathrm{~nm}$ ) and a scattering intensity-weighed percentage of $93.7 \%$ (or $91 \%$ ) for the primary fraction of LDH NPs were achieved, and TEM micrographs (Figure 3) show that these NPs were agglomerated clusters of primary NPs. After 5h of HT, the clusters of primary NPs fully coalesced to form secondary NPs via aggregational growth mechanism,[13] with a mean $\mathrm{r}_{\mathrm{H}}$ of $\sim 537 \mathrm{~nm}$ and a scattering intensityweighed percentage of the primary fraction of $90 \%$. Note, longer HT time led to particle coarsening and polydispersity, but less severe compared to that observed at $85^{\circ} \mathrm{C}$. 
The HT at $51{ }^{\circ} \mathrm{C}$ gradually dispersed the severely agglomerated NPs, and after $7 \mathrm{~h}$ (inset of Figure 4 at $\mathrm{t}_{\mathrm{HT}}=7 \mathrm{~h}$ ), a nearly monodispersed stable suspension with a mean $\mathrm{r}_{\mathrm{H}}$ of $415 \mathrm{~nm}$ was measured by DLS. The slow dispersion of as-precipitated NPs, observed until $7 \mathrm{~h}$, was due to slow kinetics of the crystallization process. Between 7 and $11 \mathrm{~h}$ of HT, the individual primary NPs $(<100$ $\mathrm{nm}$ ) were clearly discernible in TEM images (Figure $3,51^{\circ} \mathrm{C}-7 \mathrm{~h}$ and $11 \mathrm{~h}$ ), but they existed in slightly agglomerated form as secondary NPs in aqueous medium; for example, a mean $\mathrm{r}_{\mathrm{H}}$ of $\sim 386 \mathrm{~nm}$ with a scattering intensity-weighed percentage of the primary fraction of $96 \%$ was measured after $11 \mathrm{~h} \mathrm{HT}$. After $15 \mathrm{~h} \mathrm{HT}$, the primary NPs coalesced to form monodispersed secondary particles (Figure $3,51{ }^{\circ} \mathrm{C}$ $15 \mathrm{~h}$ ) with a mean $\mathrm{r}_{\mathrm{H}}$ of $397 \mathrm{~nm}$. Although the use of low HT temperature $\left(51{ }^{\circ} \mathrm{C}\right)$ minimized the coarsening rate (i.e. invariant $\mathrm{r}_{\mathrm{H}}$ of $\sim 386-397 \mathrm{~nm}$ and scattering intensity-weighed percentage of the primary fraction of 96-100\% between 7-15 h), longer HT never stabilized the primary NPs, or prevented the aggregational growth mechanism.[13]

Due to the relatively low crystallinity and stability of $\mathrm{NO}_{3}{ }^{-}$-intercalated $\mathrm{LDH}$ NPs, compared to those of $\mathrm{CO}_{3}{ }^{2-}$-intercalated ones, $[16,21]$ after $\mathrm{HT}$, the surface charge density and the hydration enthalpy at edge sites are insufficient to stabilize the individual primary NPs by electrostatic stabilization and hydration. Therefore, crystallized primary NPs further diminish the surface energy by agglomeration, although to a much lower extent compared to the as-precipitated NPs. In this study, the ideal HT window for achieving monodispersed $\mathrm{Zn}_{2} \mathrm{Al}(\mathrm{OH})_{6}\left(\mathrm{NO}_{3}\right) \cdot x \mathrm{H}_{2} \mathrm{O}$ NPs were determined to be between 70 and $85{ }^{\circ} \mathrm{C}$ for $3-5 \mathrm{~h}$. To date, with respect to the particle size, PSD, and reasonable tht, the best HT condition of $80{ }^{\circ} \mathrm{C}$ for $3 \mathrm{~h}$ gave rise to NPs with a mean $\mathrm{r}_{\mathrm{H}}$ of $436.7 \mathrm{~nm}$ NPs and a primary fraction with a scattering intensity-weighed percentage of $98.7 \%$. Although the $\mathrm{NO}_{3}$-intercalated LDH is widely accepted as the most ideal composition due the ease of post-synthesis replacement with an applicationspecific anion, a narrow HT processing window (as determined here) perhaps is a reason why there are no literature reports on the synthesis of monodispersed $\mathrm{NO}_{3}{ }^{-}$-intercalated LDH NPs.

\subsection{Size difference between the cointercalated anions-induced phase separation}

Figure 5a shows $\mathrm{XRD}$ patterns of the as-precipitated $\mathrm{Zn}_{2} \mathrm{Al}(\mathrm{OH})_{6}\left(\mathrm{NO}_{3}\right)_{y}\left(\mathrm{CO}_{3}\right)_{0.5(1-\mathrm{y})} \cdot x \mathrm{H}_{2} \mathrm{O}$ NPs (for $\mathrm{y}=0.7$ ) and crystalline NPs as they transform to the crystalline phase upon HT (at 70 and $85{ }^{\circ} \mathrm{C}$ for $12 \mathrm{~h})$. The initial broad peak centered at $2 \theta$ of $\sim 11^{\circ}$ corresponding to the $(003)$ planes for the asprecipitated NPs gradually separates into two distinct peaks (centered at $2 \theta$ of 10 and $11.6^{\circ}$ ) upon HT. The distinct latter peaks corresponding to the (003) planes of $\mathrm{NO}_{3}{ }^{-}$-intercalated and $\mathrm{CO}_{3}{ }^{2-}$-intercalated LDH NPs, respectively, indicate phase separation. Interestingly, the DLS data in Figure $5 b$ for this 
composition, exhibiting a bimodal distribution with $81.29 \%$ of the primary fraction (mean $\mathrm{r}_{\mathrm{H}} \sim 777.8$ $\mathrm{nm}$ ) and $18.7 \%$ of the secondary fraction (mean $r_{H} \sim 238.3 \mathrm{~nm}$ ). Moreover, since the MPS is dictated by the composition-dependent formation mechanisms and coarsening rates described earlier, these primary and secondary fractions can be correlated with the $\mathrm{NO}_{3}{ }^{-}$-rich and $\mathrm{CO}_{3}{ }^{2-}$-rich $\mathrm{LDHs}$, respectively. Literature data (Table 1)[17] suggests that mixed $\left(\mathrm{CO}_{3}{ }^{2-}, \mathrm{NO}_{3}{ }^{-}\right)$-cointercalated $(\mathrm{Co}, \mathrm{Al})$-LDH is less stable than pure $\mathrm{CO}_{3}{ }^{2-}$-intercalated $\mathrm{LDH}$, and considering the low magnitude of the (configurational) entropy of mixing $\left(1-5 \mathrm{~J} \cdot \mathrm{mol}^{-1}\right)$, the positive enthalpy of mixing $\left(\Delta \mathrm{H}_{\text {mix }}{ }^{0}\right)$ can drive phase separation in mixed anions-cointercalated LDH compositions provided the kinetic barriers can be overcome. Indeed, Figure 5a illustrates the propensity of phase separation in $\mathrm{Zn}_{2} \mathrm{Al}(\mathrm{OH})_{6}\left(\mathrm{NO}_{3}\right)_{0.7}\left(\mathrm{CO}_{3}\right)_{0.15} \cdot x \mathrm{H}_{2} \mathrm{O} \mathrm{NPs}_{\text {as }}$ the $\mathrm{T}_{\mathrm{HT}}$ increases.

(a)

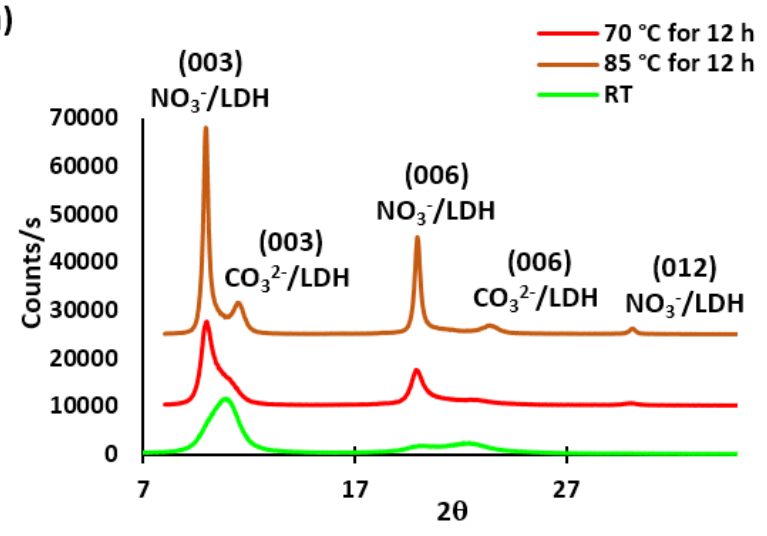

(b)

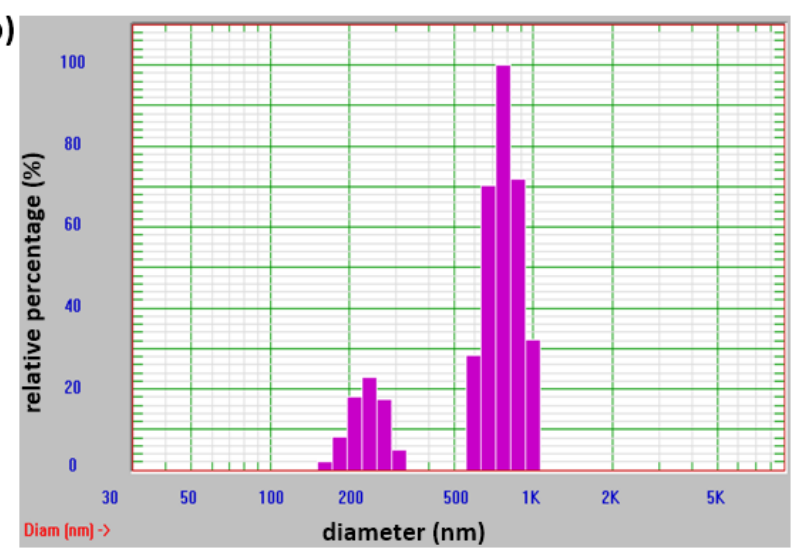

Figure 5. Effect of hydrothermal treatments on the phase stability and scattering intensity-weighted PSD. (a) Evolution of XRD patterns of $\mathrm{Zn}_{2} \mathrm{Al}(\mathrm{OH})_{6}\left(\mathrm{NO}_{3}\right)_{0.7}\left(\mathrm{CO}_{3}\right)_{0.15} \times \mathrm{xH}_{2} \mathrm{O}$ NPs from coprecipitation at room temperature to hydrothermally treated at 70 and $85{ }^{\circ} \mathrm{C}$ for $12 \mathrm{~h}$. (b) Bimodal PSD measured by DLS after HT at $85{ }^{\circ} \mathrm{C}$ for $12 \mathrm{~h}$.

Table 1. Standard enthalpy of formation for pure $\mathrm{CO}_{3}{ }^{2-}$-intercalated and mixed $\left(\mathrm{CO}_{3}{ }^{2-}, \mathrm{NO}_{3}{ }^{-}\right)-$ cointercalated LDHs

\begin{tabular}{|l|l|}
\hline LDH composition & $\left.\Delta \mathbf{H}_{\mathbf{f}}^{\mathbf{0}} \mathbf{( k J / m o l}\right)$ \\
\hline $\mathrm{Co}_{0.756} \mathrm{Al}_{0.244}(\mathrm{OH})_{2}\left(\mathrm{CO}_{3}\right)_{0.122} \cdot 0.805 \mathrm{H}_{2} \mathrm{O}$ & $-1044.17 \pm 2.50[17]$ \\
\hline $\mathrm{Co}_{0.756} \mathrm{Al}_{0.244}(\mathrm{OH})_{2}\left[\left(\mathrm{CO}_{3}\right)_{0.1202}\left(\mathrm{NO}_{3}\right)_{0.0036} \cdot 0.810 \mathrm{H}_{2} \mathrm{O}\right.$ & $-967.89 \pm 3.33[17]$ \\
\hline
\end{tabular}

To determine the range of $\mathrm{CO}_{3}{ }^{2-}$ content that may cause phase separation and bimodal PSD in $(\mathrm{Zn}, \mathrm{Al})-\mathrm{LDH}$ system, cointercalated $\mathrm{Zn}_{2} \mathrm{Al}(\mathrm{OH})_{6}\left(\mathrm{NO}_{3}\right)_{\mathrm{y}}\left(\mathrm{CO}_{3}\right)_{0.5(1-\mathrm{y})} \cdot x \mathrm{H}_{2} \mathrm{O}$ NPs, with $\mathrm{y}=0,0.2,0.3,0.4$, 0.5, 0.6, 0.7, 0.8, 0.9 and 1.0, were coprecipitated at RT followed by HT at $85{ }^{\circ} \mathrm{C}$ for 3 and/or $12 \mathrm{~h}$. The results of DLS are tabulated in Table 2. Note, the $3 \mathrm{~h}$ HT was used for samples with low stability and having propensity for rapid coarsening, which in turn would cause a bimodal distribution that is unrelated to phase separation. The $12 \mathrm{~h} \mathrm{HT}$ was used to illustrate the difference in the mean $\mathrm{r}_{\mathrm{H}}$ due to the 
difference in the coarsening rate of phase-separated, $\mathrm{NO}_{3}{ }^{-}$-rich and $\mathrm{CO}_{3}{ }^{2-}$-rich fractions. In the composition range, $0.9 \geq \mathrm{y} \geq 0.6$, pronounced bimodal PSD due to phase separation were observed after $3 \mathrm{~h} \mathrm{HT}$ at $85^{\circ} \mathrm{C}$, and the difference between the mean $\mathrm{r}_{\mathrm{H}}$ of separated fractions was further enhanced after $12 \mathrm{~h}$ of HT. Based on the aforementioned observations and discussions, and trends in available thermodynamic data,[17] one may surmise that $\mathrm{Zn}_{2} \mathrm{Al}(\mathrm{OH})_{6}\left(\mathrm{NO}_{3}\right)_{\mathrm{y}}\left(\mathrm{CO}_{3}\right)_{0.5(1-\mathrm{y})} \cdot \mathrm{xH}_{2} \mathrm{O}$ NPs with $0.5 \geq \mathrm{y} \geq$ 0.2 are probably thermodynamically metastable, and experimental observation of monodispersed PSD is suggestive of kinetic inhibition of phase separation at $85^{\circ} \mathrm{C}$.

Table 2. Mean $\mathrm{r}_{\mathrm{H}}$ and PSD of hydrothermally treated $\mathrm{Zn}_{2} \mathrm{Al}(\mathrm{OH})_{6}\left(\mathrm{NO}_{3}\right)_{\mathrm{y}}\left(\mathrm{CO}_{3}\right)_{0.5(1-\mathrm{y})} \cdot \mathrm{xH}_{2} \mathrm{O}$ NPs

\begin{tabular}{|c|c|c|c|c|}
\hline \multirow{2}{*}{$\begin{array}{c}\text { LDH } \\
\text { Composition, } y\end{array}$} & \multicolumn{2}{|c|}{ HT: $85^{\circ} \mathrm{C}$ for $3 \mathrm{~h}$} & \multicolumn{2}{|c|}{ HT: $85^{\circ} \mathrm{C}$ for $12 \mathrm{~h}$} \\
\hline & Primary fraction & Secondary fraction & Primary fraction & Secondary fraction \\
\hline 0.0 & \multicolumn{2}{|c|}{ I } & \multicolumn{2}{|c|}{$200(100 \%)^{*}$} \\
\hline 0.2 & \multicolumn{2}{|c|}{ / } & \multicolumn{2}{|c|}{$218.4(100 \%)^{*}$} \\
\hline 0.3 & \multicolumn{2}{|c|}{1} & \multicolumn{2}{|c|}{$231.7(100 \%)^{*}$} \\
\hline 0.4 & \multicolumn{2}{|c|}{ l } & \multicolumn{2}{|c|}{$253.6(100 \%)^{*}$} \\
\hline 0.5 & \multicolumn{2}{|c|}{ I } & \multicolumn{2}{|c|}{$331.3(100 \%)^{*}$} \\
\hline 0.6 & $363.5(75.72 \%)$ & $153.5(31.72 \%)^{1}$ & $512(80 \%)$ & $200(20 \%)^{1}$ \\
\hline 0.7 & $536.3(65.33 \%)$ & $196.8(34.67 \%)^{t}$ & $777.8(81.29 \%)$ & $238.3(18.70 \%)^{1}$ \\
\hline 0.8 & \multicolumn{2}{|c|}{ I } & $1009.3(75.66 \%)$ & $282.9(24.34 \%)^{t}$ \\
\hline 0.9 & $645.3(71.52 \%)$ & $210.8(28.48 \%)^{t}$ & \multicolumn{2}{|c|}{ I } \\
\hline 1.0 & $416.4(98.55 \%)$ & $46.2(1.45 \%)^{\mathrm{t}}$ & \multicolumn{2}{|c|}{ / } \\
\hline
\end{tabular}

${ }^{*}$ Gaussian MPS used if $\chi^{2} \leq 3 ;{ }^{1}$ MPS fitted by NICOMP-analyzed MPS used when $\chi^{2}>3 \cdot[1]$

Since the application target at hand is nanomedicine, the observed phase separation and consequent bimodal distribution in the $\mathrm{NO}_{3}{ }^{-}$-rich $\mathrm{LDH}$ compositions is detrimental. Therefore, identification of parameters based on existing theories of phase separation and avoidance of phase separation are critical. It is well-known that large differences in ionic potential $(\mathrm{z} / \mathrm{r}$, where $\mathrm{z}$ is the charge and $\mathrm{r}$ is the radius) and electrostatic bond strength (z/CN, where $\mathrm{CN}$ is the coordination number) $[22,23]$ influence the temperature-dependent miscibility in solid solutions. In LDH systems, the synergistic effect of $\mathrm{z}, \mathrm{r}$, and $\mathrm{CN}$ of anions within the interlayer influences the $\mathrm{d}_{003}$ interlayer spacing, and therefore, the magnitude and sign of $\Delta \mathrm{H}_{\text {mix }}{ }^{0}$, which in turn dictates the tendency for phase separation in mixed anions-cointercalated systems at a given temperature. To lend credence to this idea, mixed $\left(\mathrm{CO}_{3}{ }^{2-}, \mathrm{Cl}^{-}\right)$cointercalated (Zn, Al)-LDH NPs were synthesized and tested for phase separation; note, literature data indicate that individual $\mathrm{Cl}^{-}$and $\mathrm{CO}_{3}{ }^{2-}$-intercalated $\mathrm{LDH}$ have identical $\mathrm{d}_{003}$ interlayer spacing.[24] The exact composition tested was $\mathrm{Zn}_{2} \mathrm{Al}(\mathrm{OH})_{6}(\mathrm{Cl})_{0.7}\left(\mathrm{CO}_{3}\right)_{0.15} \cdot x \mathrm{H}_{2} \mathrm{O}$ so as to compare with the $\mathrm{Zn}_{2} \mathrm{Al}(\mathrm{OH})_{6}\left(\mathrm{NO}_{3}\right)_{0.7}\left(\mathrm{CO}_{3}\right)_{0.15} \cdot x \mathrm{H}_{2} \mathrm{O} \mathrm{NP}$ system that had exhibited phase separation and pronounced bimodal PSD. The XRD pattern of $\mathrm{Zn}_{2} \mathrm{Al}(\mathrm{OH})_{6}(\mathrm{Cl})_{0.7}\left(\mathrm{CO}_{3}\right)_{0.15} \cdot x \mathrm{H}_{2} \mathrm{O}$ NPs after HT at $85{ }^{\circ} \mathrm{C}$ for $5 \mathrm{~h}$ and the corresponding PSD by DLS are shown in Figure 6a and b, respectively. Clearly, the mixed $\left(\mathrm{Cl}^{-}\right.$, 
$\mathrm{CO}_{3}{ }^{2-}$ )-cointercalated ( $\left.\mathrm{Zn}, \mathrm{Al}\right)$-LDH NPs have one $\mathrm{d}_{003}$ interlayer spacing, but whether phase separation exists cannot be conclusive. However, despite the difference in growth mechanisms and coarsening rates of individual $\mathrm{Cl}^{-}$and $\mathrm{CO}_{3}{ }^{2-}$-intercalated $\mathrm{LDH}$, a single Gaussian distribution centered at $303.4 \mathrm{~nm}$ was observed clearly indicating that phase separation did not occur. Note, the growth mechanism of $\mathrm{Cl}^{-}$intercalated $(\mathrm{Zn}, \mathrm{Al})$-LDH NPs was also determined to be aggregational growth as $\mathrm{NO}^{-}$-intercalated LDH NPs due to their similar stability (data not shown here).

(a)
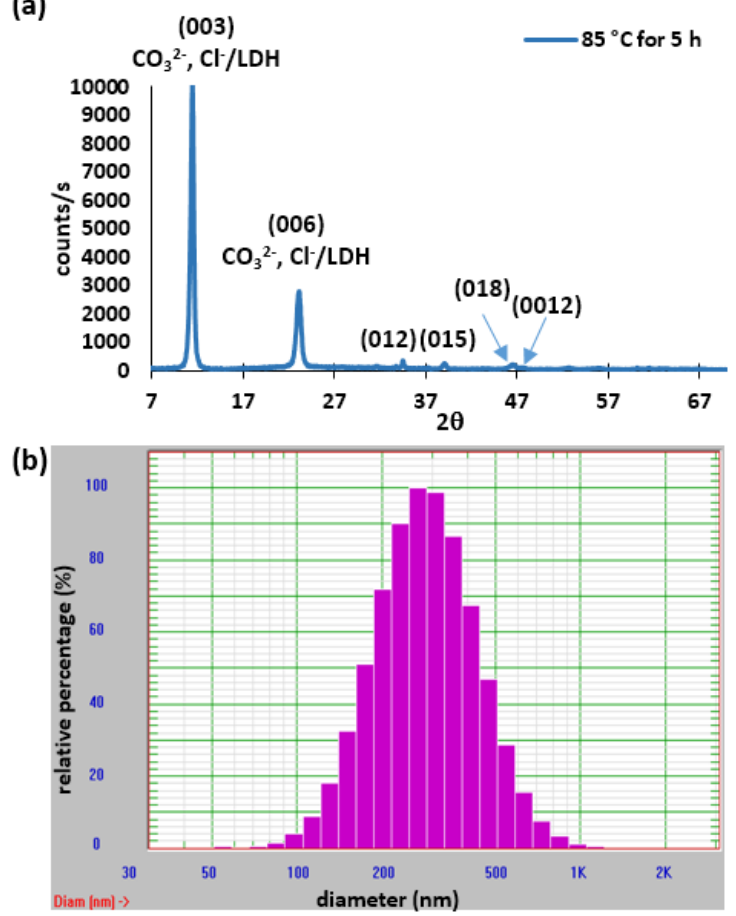

Figure 6. XRD pattern of $\mathrm{Zn}_{2} \mathrm{Al}(\mathrm{OH})_{6}(\mathrm{Cl})_{0.7}\left(\mathrm{CO}_{3}\right)_{0.15} \cdot \mathrm{xH}_{2} \mathrm{O}$ NPs, hydrothermally treated at $85^{\circ} \mathrm{C}$ for $5 \mathrm{~h}(\mathrm{a})$, and the corresponding single Gaussian PSD measured by DLS technique (b)

\subsection{Cointercalated anion composition-controlled coarsening and size distribution}

The solubility of the LDH NPs is governed by the cationic composition of the double hydroxide, the intercalated anions, and temperature.[16, 17, 21] As previously demonstrated, the higher dissolution rate led to a higher coarsening rate of $\mathrm{NO}_{3}{ }^{-}$-intercalated NPs compared to that of $\mathrm{Zn}_{2} \mathrm{Al}(\mathrm{OH})_{6}\left(\mathrm{NO}_{3}\right)_{0.3}\left(\mathrm{CO}_{3}\right)_{0.35} \times \mathrm{H}_{2} \mathrm{O}$ NPs at the same $\mathrm{T}_{\text {HT. }}$. Here, we show that one can tailor the size of LDH NPs by controlling the coarsening rate through the systematic variation of cointercalated anion compositions, since the coarsening rate is inversely proportional to the stability determined by the intercalated anion composition. As shown in Table 2, $\mathrm{HT}$ of $\mathrm{Zn}_{2} \mathrm{Al}(\mathrm{OH})_{6}\left(\mathrm{NO}_{3}\right)_{\mathrm{y}}\left(\mathrm{CO}_{3}\right)_{0.5(1-\mathrm{y})} \cdot x \mathrm{H}_{2} \mathrm{O}(\mathrm{y}=0$, $0.2,0.3,0.4,0.5)$ at $85^{\circ} \mathrm{C}$ for $12 \mathrm{~h}$ led to monodispersed LDH NPs with gradual increase in NP size $(\sim 200-400 \mathrm{~nm})$ as the $\mathrm{CO}_{3}{ }^{2-}$ content decreased. Figure 7 shows bright-field TEM images for the 
corresponding compositions; note, with decreasing $\mathrm{CO}_{3}{ }^{2-}$ content, the NPs become thinner with their edges more rounded.
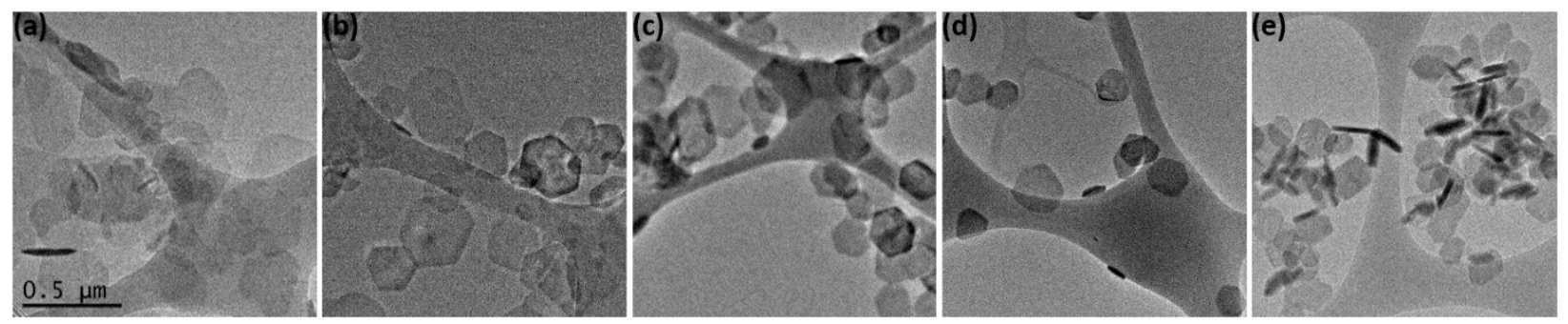

Figure 7. Effect of cointercalated anion compositions on the particle size of $\mathrm{Zn}_{2} \mathrm{Al}(\mathrm{OH})_{6}\left(\mathrm{NO}_{3}\right)_{\mathrm{y}}\left(\mathrm{CO}_{3}\right)_{0.5(1-y)} \cdot \mathrm{xH}_{2} \mathrm{O} \mathrm{NPs}$ : (a) y $=0.5$, (b) $\mathrm{y}=0.4$, (c) $\mathrm{y}=0.3$, (d) $\mathrm{y}=0.2$, and (e) $\mathrm{y}=0$.

Clearly, when y $<0.5$, monodispersed PSD of $\mathrm{Zn}_{2} \mathrm{Al}(\mathrm{OH})_{6}\left(\mathrm{NO}_{3}\right)_{\mathrm{y}}\left(\mathrm{CO}_{3}\right)_{0.5(1-\mathrm{y})} \cdot x \mathrm{H}_{2} \mathrm{O}$ NPs may be achieved at $\mathrm{T}_{\mathrm{HT}}$ of $85^{\circ} \mathrm{C}$ for $12 \mathrm{~h}$, since phase separation only occurs in compositions for $\mathrm{y}>0.5$. Apparently, at a given $\mathrm{T}_{\mathrm{HT}}$, the difference in the coarsening rates (which are temperature dependent) between the end members (pure $\mathrm{NO}_{3}{ }^{-}$-intercalated and pure $\mathrm{CO}_{3}{ }^{2-}$-intercalated ( $\left.\mathrm{Zn}, \mathrm{Al}\right)$ - $\mathrm{LDH}$ ) governs the composition (y) between the single phase and two-phase regions. This idea, qualitatively depicted in Figure 8, underscores the importance of the judicious selection of $\mathrm{T}_{\mathrm{HT}}$ for various combinations of cations and anions to achieve monodispersed NPs with controlled size variations.

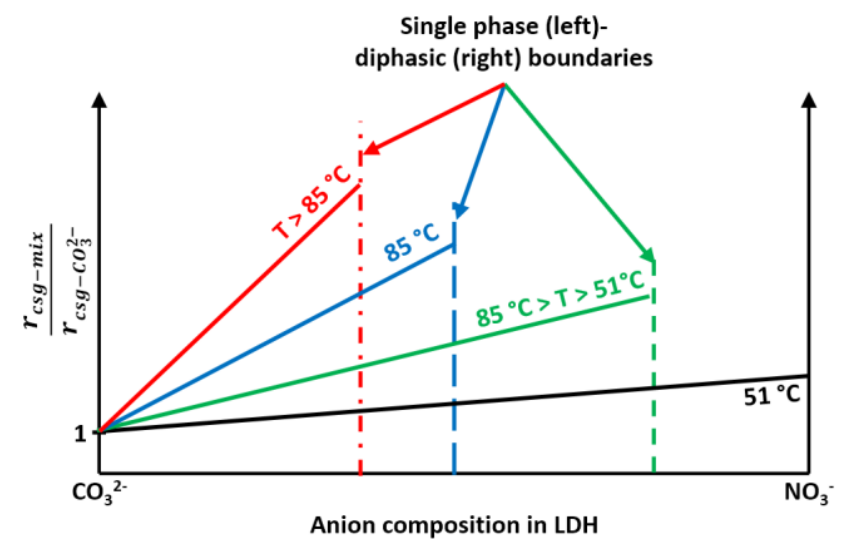

Figure 8. Proposed phase stability and relative coarsening rate $\left(\mathrm{r}_{\mathrm{csg}}\right)$ of LDH NPs as functions of anion composition and hydrothermal treatment temperatures

In summary, Figure 9 is a schematic representation of the time evolution of the nanostructure and formation mechanisms as a function of intercalated anion compositions (described in Sections 3.1, 3.2 and 3.3). 

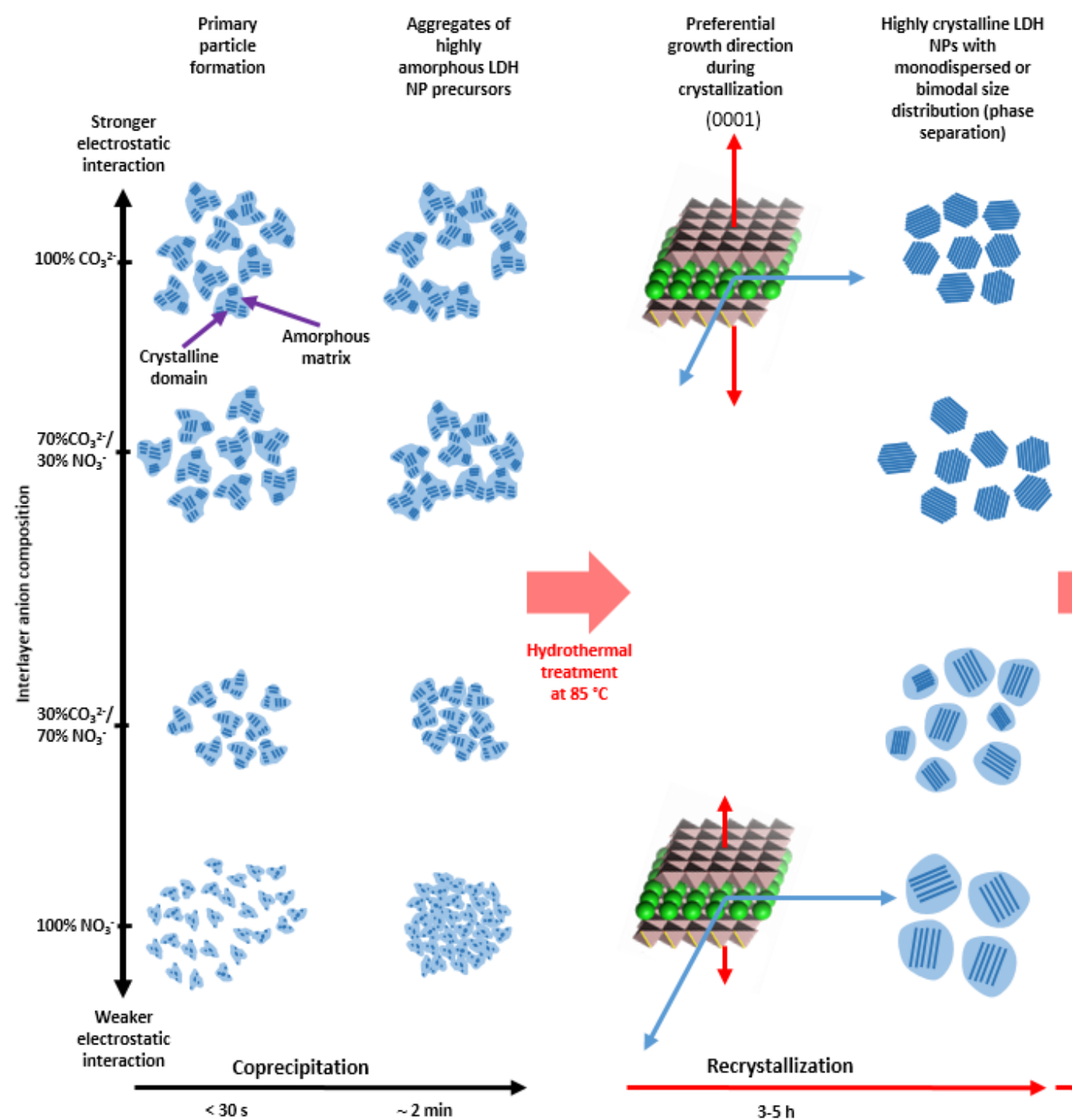

Continuous growth

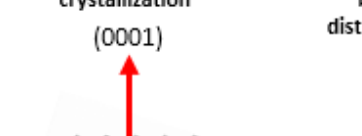

separation)
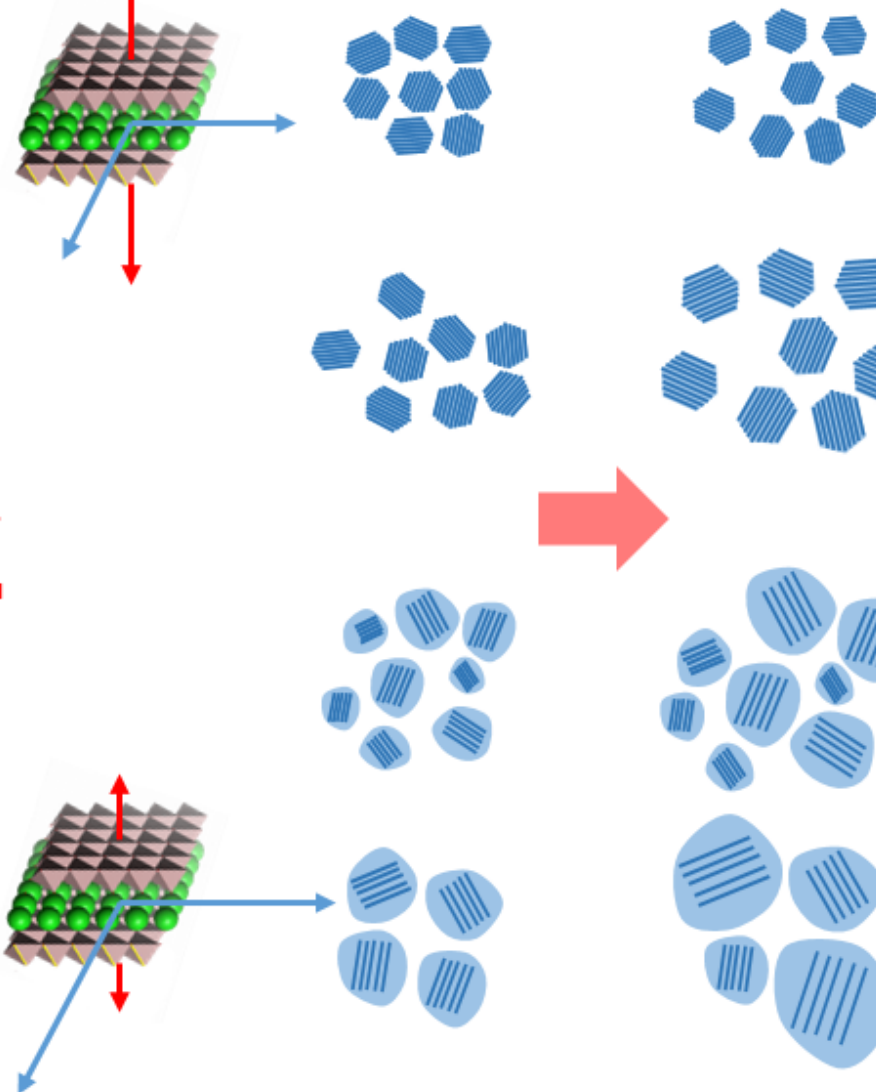

Recrystallization

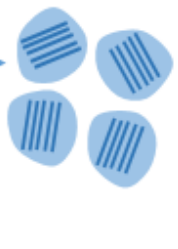

$3-5 \mathrm{~h}$

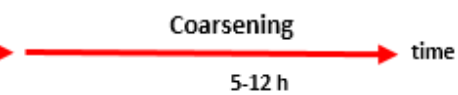

Figure 9 Schematic representation of the effect of (co)intercalated anion compositions on the nanostructure evolution (i.e. phase, particle size, particle size distribution, and morphology) and the corresponding formation mechanisms (i.e. agglomeration, crystallization, aggregational growth, phase separation, and coarsening) following coprecipiation and hydrothermal treatment.

\section{CONCLUSIONS}

This study has demonstrated the effect of (co)intercalated anion compositions on the nanostructure evolution (i.e. phase, particle size, PSD, and morphology) and the corresponding formation mechanisms (i.e. agglomeration, crystallization, aggregational growth, phase separation, and coarsening) following coprecipiation and HT. By using TEM and DLS, it was determined that crystalline LDH NPs evolve from highly amorphous primary particles formed in the initial RT coprecipitation. Such amorphous primary particles have a discoid shape due to the slower growth rate of the (0001) planes that have both the highest surface charge density and hydration enthalpy. Consequently, agglomeration of primary particles occurred mainly at the edge sites, where the charge 
density and hydration enthalpy are the lowest. Upon crystallization, the agglomerated $\mathrm{Zn}_{2} \mathrm{Al}(\mathrm{OH})_{6}\left(\mathrm{NO}_{3}\right)_{0.3}\left(\mathrm{CO}_{3}\right)_{0.35} \cdot x \mathrm{H}_{2} \mathrm{O}$ primary NPs re-dispersed, but the $\mathrm{Zn}_{2} \mathrm{Al}(\mathrm{OH})_{6}\left(\mathrm{NO}_{3}\right) \cdot x \mathrm{H}_{2} \mathrm{O}$ NPs with much lower stability and higher disorder (especially at the edges) exhibited irreversible agglomeration, and transformed into secondary nanoparticles via aggregational growth. If crystallization was carried out under conditions that minimized the coarsening process, individual primary particles observed in TEM were found by DLS to exist as monodispersed clusters in an aqueous environment that transformed with time to secondary nanoparticles. It is believed that the size of the secondary NPs is dictated by the extent of irreversible agglomeration, which depends on the surface charge density and hydration enthalpy of the crystallized primary NPs.

The phase stability study indicated the importance of $\mathrm{Z}, \mathrm{r}$, and $\mathrm{CN}$ of the anions and their synergetic influence on the $\mathrm{d}_{003}$ interlayer spacing; cointercalated anions with significantly different $\mathrm{d}_{003}$ drove phase separation that led to the observed bimodal size distribution.

It was shown that the coarsening rates were controlled through the cointercalated anion compositions. By gradually increasing the cointercalation ratio of $\mathrm{NO}_{3}{ }^{-}$to $\mathrm{CO}_{3}{ }^{2-}$ and staying within the phase separation-free composition range, the increasing coarsening rates led to monodispersed $\mathrm{Zn}_{2} \mathrm{Al}(\mathrm{OH})_{6}\left(\mathrm{NO}_{3}\right)_{\mathrm{y}}\left(\mathrm{CO}_{3}\right)_{0.5(1-\mathrm{y})} \cdot \mathrm{xH}_{2} \mathrm{O}(0.5 \geq \mathrm{y} \geq 0)$ NPs with systematic increase in the particle size from $\sim 200$ to $400 \mathrm{~nm}$ after $\mathrm{HT}$ at $85^{\circ} \mathrm{C}$ for $12 \mathrm{~h}$.

\section{AUTHOR INFORMATION}

\section{Corresponding Author}

* E-mail: sandwip.dey@asu.edu

\section{Funding Sources}

The current work was supported by National Cancer Institute, National Institutes of Health (1R21CA133618), National Science Foundation (CBET-0829128), and ASU Foundation's Women \& Philanthropy (WZ91010).

\section{ACKNOWLEDGMENT}

SKD acknowledges financial support from the National Cancer Institute, National Institutes of Health (1R21CA133618), National Science Foundation (CBET-0829128), and ASU Foundation's Women \& Philanthropy (WZ91010). The authors gratefully acknowledge the use of facilities within the LeRoy Eyring Center for Solid State Science at Arizona State University, and we are grateful to Dr. Robert Wang, and Dr. Karl Weiss of ASU for assistance with DLS, and TEM. 


\section{REFERENCES}

[1] NICOMP 380 DLS User Manual, Particle Sizing Systems, Inc., 2006.

[2] L.L. Hench, J.M. Polak, Third-generation biomedical materials, Science, 295 (2002) 1014-+.

[3] L.L. Hench, Bioceramics, Journal of the American Ceramic Society, 81 (1998) 1705-1728.

[4] L.L. Hench, J. Wilson, An Introduction to Bioceramics, World Scientific, Singapore; River Edge, N.J., 1993.

[5] H.L. L., Ceramics, glasses, and composites in medicine, Medical Instrumentation, 7 (1973) 136-144.

[6] O.C. Farokhzad, R. Langer, Nanomedicine: Developing smarter therapeutic and diagnostic modalities, Advanced Drug Delivery Reviews, 58 (2006) 1456-1459.

[7] H.-C. Huang, S. Barua, G. Sharma, S.K. Dey, K. Rege, Inorganic nanoparticles for cancer imaging and therapy, Journal of Controlled Release, (2011).

[8] R.F. Service, NANOTECHNOLOGY Nanoparticle Trojan Horses Gallop From the Lab Into the Clinic, Science, 330 (2010) 314-315.

[9] R.P. Sear, The non-classical nucleation of crystals: microscopic mechanisms and applications to molecular crystals, ice and calcium carbonate, International Materials Reviews, 57 (2012) 328-356. [10] A. Navrotsky, Energetics of nanoparticle oxides: interplay between surface energy and polymorphism, Geochemical Transactions, 4 (2003) 34-37.

[11] S.Y. Chung, Y.M. Kim, J.G. Kim, Y.J. Kim, Multiphase transformation and Ostwald's rule of stages during crystallization of a metal phosphate, Nature Physics, 5 (2009) 68-73.

[12] A. Navrotsky, Energetic clues to pathways to biomineralization: Precursors, clusters, and nanoparticles, Proc. Natl Acad. Sci. USA, 101 (2004) 12096-12101.

[13] J.F. Banfield, S.A. Welch, H.Z. Zhang, T.T. Ebert, R.L. Penn, Aggregation-based crystal growth and microstructure development in natural iron oxyhydroxide biomineralization products, Science, 289 (2000) 751-754.

[14] Q. Zhang, S.-J. Liu, S.-H. Yu, Recent advances in oriented attachment growth and synthesis of functional materials: concept, evidence, mechanism, and future, Journal of Materials Chemistry, 19 (2009) 191-207.

[15] S. Miyata, ANION-EXCHANGE PROPERTIES OF HYDROTALCITE-LIKE COMPOUNDS, Clays and Clay Minerals, 31 (1983) 305-311.

[16] R.K. Allada, J.D. Pless, T.M. Nenoff, A. Navrotsky, Thermochemistry of hydrotalcite-like phases intercalated with CO32-, NO3-, Cl-, I-, and ReO4, Chemistry of Materials, 17 (2005) 2455-2459.

[17] R.K. Allada, A. Navrotsky, H.T. Berbeco, W.H. Casey, Thermochemistry and aqueous solubilities of hydrotalcite-like solids, Science, 296 (2002) 721-723.

[18] D. Hanaor, M. Michelazzi, C. Leonelli, C.C. Sorrell, The effects of carboxylic acids on the aqueous dispersion and electrophoretic deposition of ZrO2, Journal of the European Ceramic Society, 32 (2012) 235-244.

[19] R. Greenwood, K. Kendall, Selection of suitable dispersants for aqueous suspensions of zirconia and titania powders using acoustophoresis, Journal of the European Ceramic Society, 19 (1999) 479488.

[20] J.J. De Yoreo, P.G. Vekilov, Principles of crystal nucleation and growth, Biomineralization, 54 (2003) 57-93.

[21] R.K. Allada, E. Peltier, A. Navrotsky, W.H. Casey, C.A. Johnson, H.T. Berbeco, D.L. Sparks, Calorimetric determination of the enthalpies of formation of hydrotalcite-like solids and their use in the geochemical modeling of metals in natural waters, Clays and Clay Minerals, 54 (2006) 409-417.

[22] A.R. West, Solid State Chemistry and Its Applications, John Wiley \& Sons 1989.

[23] M. Fevre, C. Varvenne, A. Finel, Y. Le Bouar, Influence of atomic size mismatch on binary alloy phase diagrams, Philosophical Magazine, 93 (2013) 1563-1581. 
[24] T. Sato, T. Wakabayashi, M. Shimada, ADSORPTION OF VARIOUS ANIONS BY MAGNESIUM ALUMINUM-OXIDE (MG0.7AL0.3O1.15), Industrial \& Engineering Chemistry Product Research and Development, 25 (1986) 89-92. 


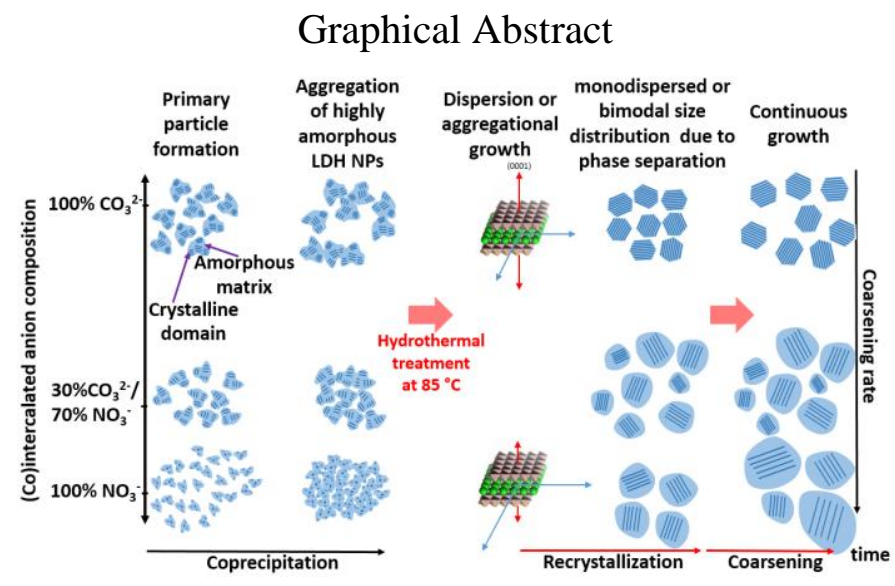

